16. DAChO, F. R-5271, Op. 1, Spr. 5, Spysky chlenov oblredkollegyy toma "Ystoryja gorodov y sel Chernygovskoj oblasty", rabochyh grupp, rajredkollegyj (28 sichnja 1965 r. 12 sichnja 1970 r.), 145 ark.

17. DAChO, F. R-5271, Op. 1, Spr. 4, Plani raboti oblastnoj redkollegyy «Ystoryy gorodov y sël Chernygovskoj oblasty»; ynformacyja o hode raboti (avgust 1962 g. - 22 dekabrja 1970 g.), 149 ark.

18. Tkachenko, V., Ignatenko, M. (1996). Rozvytok istorychnogo krajeznavstva u Chernigivs'komu pedinstytuti im.
T. G. Shevchenka. Ljudyna, suspil'stvo, kul'tura: istorija ta suchasnist'. Chernigiv, 10-12.

19. Bibliografichnyj pokazhchyk naukovyh prac' vykladachiv Chernigivs'kogo derzhavnogo pedagogichnogo instytutu im. T. G. Shevchenka (1976-1985) (1986). Chernigiv: Chernigivs'kyj derzhavnyj pedagogichnyj instytut im. T. G. Shevchenka, 168.

20. DAChO, F. R-608, Op. 2, Spr. 746, Otchet o nauchnoj rabote studentov v ynstytute (1975 g.), 26 ark.

Дата надходження рукопису 27.03.2015

Ігнатенко Марина Миколаївна, доктор історичних наук, професор, кафедра історії України, Київський університет імені Бориса Грінченка, вул. Бульварно-Кудрявська, 18/2, м. Київ, Україна, 04053

E-mail :8117836@ukr.net

\author{
UDC 62(091) \\ DOI: $10.15587 / 2313-8416.2015 .40448$
}

\title{
KHARKIV PLANT OF SELF-PROPELLED CHASSIS - THE PRODUCER OF UNIQUE NON-CLASSIC LAYOUT TRACTORS
}

\author{
(C) A. G. Kryvokon
}

The article is about the history of Kharkiv Plant of Self-propelled Chassis, producer of unconventional layout tractors - so-called self-propelled chassis. The information about tractors' technical options and its models is highlighted. The facts about the creation, design and modifications of self-propelled chassis, their usage in different specific areas are uncovered

Keywords: tractorbuilding, self-propelled chassis, classic layout, tractor design, agriculture

Стаття присвячена історії Харківського заводу транспортних самохідних шасі, виробника тракторів нетрадииійної компоновки - так званих самохіднх шасі. Подано інформачію про технічні характеристики тракторів, а також їх моделі. Висвітлюються факти про створення, проектування $i$ модифікаџії самохідних шасі, їх використання в різних спещіальних сферах

Ключові слова: тракторобудування, самохідні шасі, класична компоновка, конструкція трактора, сільське господарство

\section{Introduction}

Tractorbuilding is considered to be one of the most important branches of agricultural engineering in the world. Ukraine has a great experience in tractor producing. This is explained by the fact that our country has huge land resources, agriculture is one of the priorities of the state economy, and tractors have been in demand everywhere and always.

The tractorbuilding has gone all the glorious way and includes well-developed research and production base, powerful design departments, network of machine stations. The domestic tractors as well as foreign units are still working in our fields today.

\section{Problem statement}

Nevertheless, the subject of the history of the tractorbuilding in the USSR and in Ukraine is still poorly understood despite the fact that the developments of various types of machinery and tractors as well as the scope of production in the last hundred years are staggering.

Today the situation of the domestic tractor industry is quite deplorable. It is regrettable that due to the various problems and shortcomings of the domestic economy our tractor industry today is almost underdeveloped. There is a risk that within a couple of decades we will only use the foreign manufactured models. Thus, the glorious history of the domestic tractorbuilding just sinks into oblivion. We do not want if this will be true because we have a significant positive experience in this industry that is not ashamed to transfer to subsequent generations not only in our country but also abroad. Therefore, the important objective of this publication is to review the history of the creation, manufacturing, implementation and operation of domestic tractors.

The deep analysis of the tractorbuilding history has been done by a wide range of scientists. However, there is one type of tractor that has not been mentioned in the articles: self-propelled chassis.

The aim of the article is to uncover the facts about the creation, design and modifications of selfpropelled chassis, their usage as agricultural tractors, military and civil trucks. Besides, the publication analyses the historical and design pass of the Kharkiv Plant of Self-propelled Chassis, the only one plant producing selfpropelled chassis in Ukraine, one of two such plants in former USSR, one of the few world plants that designed and developed the unusual layout tractors.

\section{Literature review}

The history of self-propelled chassis is totally unrevealed in scientific publications. Only designers and engineers of Kharkiv Plant of Self-propelled Chassis - V. Adolf, A. Vasernis, S. Libtsis - published the notes on technical specifications of non-classic layout tractors. The article is based on this works and archival documents as a chronological background. 
4. The history of self-propelled chassis and Kharkiv Plant of Self-propelled Chassis in particular

Establishing of the first steam tractor and then replacing it with the internal combustion engine inventors copied the already known for hundreds of years model of the animals strength usage (ponies, oxen, camels, llamas and others) to perform labor-intensive agricultural operations.

Traditionally, animals were used for laborintensive plowing in many countries. They were dragged behind a plowed device and the person watching the quality of plowing followed it and provided necessary corrective actions such as leaning on the handle and recessing plow blade or moving it to prevent the formation of bald spots. Therefore, first tractors were "mechanical horses" that dragged a trailer plows. Such decision was convenient to facilitate the work but created certain difficulties for managing towed implements as it were behind the back of the tractor operator. The solution was to use additional workers beyond trailed implements.

The wasp-waist tractors appeared for that to free up additional workers and to limit operation of just one tractor. This kind of tractor was constructed with the rear wheels drive from the front engine and gearbox in the form of a rotating shaft put in the bearing pipeline that connected the front and rear of the tractor. It was assumed that the working bodies of machines and tools would be set in the vacant space under the pipe with the shaft in tractor drivers' vision range. This should eliminate the need of additional employees and made a tractor driver to be able to monitor and control the working bodies with the help of lever systems, cables or hydraulic rams.

Wasp-waist tractors were issued in 1930-1940 but were not widely spread. The main reason for it was a sharp increase in the complexity of the front linkage machines and tools in the space between exes compared with rear linkage tractors of traditional layout. With the advent of hydraulic three-point rear hitch (or different versions of "triangular" etc.) benefits of rear mounting became particularly illustrative as it was easy to drive back up to the tool and connect it to the tractor quickly and simply.

The next step in agricultural machinery after wasp-waist tractors was a self-propelled chassis. There was a common opinion of experts that self-propelled chassis layout as the tractor was more promising than the classic layout tractor.

It was known that self-propelled chassis with the same engine as the classic layout tractor had better traction and grip, better handling, less traumatic crops cultivated in the works, had better performance and better fuel economy. Besides, it had a range of additional qualities such as good visibility of the working area of machines and tools, direct connection between the steering wheel and the direction of tools displacement that was more convenient for a tractor driver.

Patent for tractor layout as a self-propelled chassis was received in 1935 in Germany but it had not been designed because of The World War II. After the war many countries embarked on the project, especially there were many companies that manufactured motor vehicle chassis in Germany, including such well-known as Eicher Yebr, Tractorenfabrik, Fendt Xaver \& $\mathrm{C}^{\circ}$, Lanz Hermann and others. Among smaller firms there were Wesseler Ho
H.G. Schlepper, Huber \& Wossner OHG, Ritscher KG t.b. H, Fahr Maschinen - fabric AG.

The logic of the self-propelled chassis was quite obvious: to place the engine and gearboxes in the area of the rear wheels (over or behind). Then, instead of pipe with the rotating shaft, base frame could be installed on which machines and tools could be hanged.

An interest in the self-propelled chassis has revived in Germany, England, Switzerland, Czechoslovakia and then in the United States and other developed countries After The Second World War [1, 2].

The self-propelled chassis possess significant advantages over similar tractors of classical layout [2]:

- the best traction properties and lower specific fuel consumption per unit by increasing the coupling weight by placing the engine, clutch and gearboxes on the side or rear of the drive wheels which provided the redistribution of weight between the front and rear axles of the tractor;

- the best maneuverability and passability;

- shorter damageability of cultivated plants, especially in the processing of row crops due to the so-called "direct" link between exposure on the steering wheel and the displacements of machines and tools;

- no need for additional workers or watching working bodies of machinery and tools on the rear hitch.

Besides there were other advantages including the technique of execution of the power unit.

All of the above was the reason for the widespread development of self-propelled chassis manufacture especially in Germany where not only the large and well-known companies as "Eicher", "Fendt" but dozens of others had begun to produce various models of them.

Many experts at international conferences and symposia had predicted self-propelled chassis further development and improvement, and some of them - even the displacement traditional layout tractors on rolling works, as well as the use of self-propelled chassis as a power base in the non-agricultural industries.

However, the major drawback of self-propelled chassis was a complexity of inter-axle (front) hinge.

Scientists and engineers from different countries tried to overcome this deficiency in different ways.

Thus, German designers applied the method of moving through the machine or instrument placed in a ditch (or pit) below the level of the wheels followed by a rising and adding them to the frame.

In England (UK) the original self-propelled chassis "David Brown-2D" were issued with a spinal frame and two rotary three-point mounted systems located to the left and right of the front seat. It was easy to hang for each of them respectively right and left side mounted machine or tool, then to bring them under the backbone frame by turning the hinged system like the wings of butterfly and to put the pieces together and outweigh the frame.

Firstly, it had a little diesel engine AD2/12, twocylinder, four-stroke, air-cooled sizes $8,89 \times 10,16 \mathrm{~cm}$ $(3,5 \times 4 ")$ which developed for maximum $12 \mathrm{HP}$ and had 12 volt electric starter, weighed $163 \mathrm{~kg}$ (specific metal output was $13.58 \mathrm{~kg} / \mathrm{HP}$ which in those years was the average of normal). During operation it had been revealed that the engine power was insufficient. It was modified: reversibility increased to $1800 \mathrm{rpm}$, power increased to $14.1 \mathrm{HP}$. 
The chassis had four speed forward gears: three working - 2.24; $3.77 ; 5.23$; and one transport $-10.5 \mathrm{~km} / \mathrm{h}$. There was a rear speed $3.39 \mathrm{~km} / \mathrm{h}$. With an increase of crankshaft rotation frequency by $\sim 16 \%$ to $2090 \mathrm{rpm}$ above, the speed increased to $2.66 ; 4.45 ; 6.16$, and transport - to $12.35 \mathrm{~km} / \mathrm{h}$. This increased the reverse speed to $3.99 \mathrm{~km} / \mathrm{h}$. Chassis had a relatively low base in $1828 \mathrm{~mm}$ (about 72"), was based on the rear 6-22 and front guides tires $4-15$.

These dimensions provided a relatively low ground clearance of $380 \mathrm{~mm}$, which was not allowed to work with high row crops but only with those that have not high tops (sugar beets, potatoes, tomatoes, onions, etc.).

This chassis was in a focus of the traditional annual British tractors show in 1955. The British named new tractor «tool carriers». Production of this model was continued until 1961. There were released 2008 such self-propelled chassis.

In general, self-propelled chassis failed that led to the termination of its production. Farmers did not use a new vehicle due to the hanging difficulties, need of special machines and tools and the complexity of storage. Thus, there were some tries to create more useful vehicle.

Opperman Motocart was designed by SE Opperman in 1946 with the capacity of $8 \mathrm{HP}$ and wheel formula $3 \times 1$ that corresponded to one of the top front wheels on which gasoline engine was mounted. Motocart replaced nearly 3 horse sleds during transportation agricultural cargo. Transport speed at 4 gears was $17.7 \mathrm{~km} / \mathrm{h}$. Engine was single cylinder and four-stroke. It weight $1500 \mathrm{~kg}$ and freely drove the same load.

Czechoslovakian chassis ran over the located in the same direction machine, then raised it to a hydraulic swivel device (at $90^{\circ}$ ) and put the car in the space between axles with the temporarily hydraulically lifted one steering wheel. In Switzerland, the self-propelled chassis moved over the hinged machine or tool by the front wheels at special troughs and then put in it on the threepoint linkage behind the front axle.

As experience showed, none of these solutions was successful for self-propelled chassis competing with classic layout tractors. This restrained their development and was the reason for the phase-out of most manufacturers of selfpropelled chassis issue. Two large German firms "Eicher" and "Fendt" were the last manufacturers in the market.Manufacturing of tractors with internal combustion engines was established on the territory of Ukraine (Kharkiv, Barvenkovo, Kinchasy) before The First World War [3].

Information about development of Ukrainian tractorbuilding is gathered in State Archive of Kharkiv Region. Particularly the fund WF-5652 and fund numbered P-5592 [4] are about the history of the establishment and operation of one of the most unusual tractor plants in Ukraine and the USSR - Kharkiv Tractor Assembling Plant that then has been renamed and now is called Kharkiv Plant of Self-Propelled Chassis [5].

The Ukrainian plant was essentially the only one in Ukraine and the USSR tractor plant producing universallyrolling tractors, not traditional but fundamentally new type of the tractor layout. It was a four-wheeled self-propelled chassis tractor $4 \times 2$, i.e. with two rear-wheel drives and opened front frame for hanging machines and tools [1, 2].
KhTSZ (Kharkiv Tractor Assembling Plant) has produced self-propelled chassis since 1956 in Ukraine.

The plant was established in October 1949 according to the order of the Ministry of Local Industry of the USSR for unloading KhTZ (Kharkiv Tractor Plant named after S. Ordzhonikidze) and released a garden tractor KhTZ-7.

Initially it received engines and details especially too complex from KhTZ but then started producing independently a large range of parts and assembly units fully unloading KhTZ in this direction.

From January 1950 to March 1951 [4] the plant entered the Republican Machine Trust "Ukrmashprom" by Ministry of Machine-Building Industry of the USSR, and from April 1951 to March 1953 it was added to the General Directorate of Tractor Production by Ministry of automobile and tractor industry of the USSR.

KhTSZ was based on the ex-car factory displaced from Volgograd to Kharkiv and specialized on automobiles repairing. The plant gradually increased its production area, captured the neighboring small enterprises (crane equipment factory, foundry, etc.), even a fivestory dormitory and some private sector buildings that were demolished. The full-fledged tractor plant (without foundries) was built at the free territory.

Despite the fact that the original plant was designed for unloading KhTZ, soon there was decided to convert it to the issue of self-propelled chassis of the 0.6 tons of thrust [1].

Work on the design of self-propelled chassis mainly carried out in the 1954-1955 by the plant designers and experts of the State Union Tractor Institute (NATI).

For the chassis prototype was taken "Lantsaldog" A 12 produced in the FRG (Federal Republic of Germany). This company was not large and influential but its self-propelled chassis with a capacity of $12 \mathrm{HP}$ attracted Ukrainian constructors with simple and easily reproducible design. Besides, they hoped that the German company would not insist on the observance of the owner copyright in case of the redesign with the engine replacement. Hope was entirely justified.

The leader of self-propelled chassis design process was V. A. Adolf and then G. V. Lebedinskyi. The active participant designers were: A. I. Podrigalo (demobilized veteran of World War II) and then I. N. Serebryakov, G. N. Belinskyi, F. F. Artemov, R. M. Gimdens, A. N. Lysenko, E. A. Kizelshteyn, V. A. Nevskyi and many others. They created during a short period a lot of different designs of self-propelled chassis and classic layouts tractors on its base: wheeled and tracked including the exclusive models - crawler tractor "Eureka" on the low-pressure rubber tracks that amazed foreigners by its maneuverability and low pressure at international exhibitions. For example, this tractor moved its tracks over a bottle of champagne without crushing it.

Orienteering on German prototype at the initial design stage brought a lot of positive but it was not without flaws. The most significant drawback was the application instead of the worm gear in the steering system of the two bevel gears that hit the tractor drivers' hands (especially thumbs) when approaching the front wheel on the obstacle. It is known that the worm gear is not reversible due to high 
internal friction, i. e. a worm can rotate the wheel but it is impossible to rotate the worm with the wheel. Therefore, worm gear steering does not transmit kickback.

Until hydraulic steering was not implemented on self-propelled chassis T-16 MG, tractor drivers experienced significant discomfort from the German constructive solutions of vehicles drive transferred to the landing gear.

Issue of self-propelled chassis was launched in 1956 by the model DSSh-14 [1]. It was a diesel selfpropelled chassis capacity of $14 \mathrm{HP}$.

The single-cylinder diesel engine D-14B manufactured by Kharkiv Tractor Plant was mounted. The engine had a water-cooling. It could reach $14 \mathrm{HP}$, had an engine 1,533 litres. Diameter of the cylinder and piston stroke length was $125 \mathrm{~mm}$ at $1600 \mathrm{rpm}$ of the crankshaft.

The engine was a four-stroke, without a compressor, with compression-ignition (compression ratio was 14.5). It ran on gasoline started with a crank at a low compression ratio. The alternating-current generator G-30A2 and two front lights for illumination were used on the chassis. There were no batteries on the tractor, so that lights could illuminate the road only when the engine was running. The engine even at those times had a heavy weight of $370 \mathrm{~kg}$ without the clutch, air cleaner and radiator bracket.

Taking into account the wishes of the tractor drivers KhTSZ started, firstly, the replacement of the manual start as obsolete with the starter and, secondly, the design of a more modern air-cooled engine that get name D-16 (16 HP).

A starter ST-80B powered by a battery 6-ST-68EM was set in self-propelled chassis DSM-14M that had been issued from 1957 to 1958 [1].

Constructors replaced carburetor, magneto, candle, secondary camera in the cylinder head and the mechanism of its incorporation. Direct current was changed in the scheme of electric equipment. Travel speed was increased from 13.7 to $17.2 \mathrm{~km} / \mathrm{h}$. The length of the open frame was increased by $350 \mathrm{~mm}$ to improve the ease of hanging and longitudinal stability (against tipping back at the entrance to the steep climb).

Hard work to improve engine of chief designer G. V. Lebedinskyi, his deputies V. A. Barskyi, M. N. Serebriakov, engine bureau chief I. E. Linetskyi, his assistants L. M. Kliozh and R. M. Shindnes resulted in the development of the first Soviet air cooling tractor engine. Its weight was $210 \mathrm{~kg}$ while the previous generation engine D-14G on chassis DSSh-14M weighed almost twice more and provided not $16 \mathrm{HP}$, but only $14 \mathrm{HP}$

The use of the domestically designed and manufactured air-cooled engines simplified maintenance of the engine and chassis at whole because there was no need to care about the capricious water cooling system. The risk of engine thawing in winter was completely eliminated [1].

Chassis DVSSh-16 was produced with this engine in the 1954-1961. The D-16 engine model was a twocylinder, had a smaller diameter of the cylinder than predecessors had (95 vs. 125), slightly smaller stroke (120 vs. $125 \mathrm{~mm}$ ) but a higher compression ratio (18 vs. 14.5). It belonged to the medium speed engines (1600 rpm) but had a reserve for increasing revving. This construction was implemented in the further engine models D-21 and D-21 produced by Vladimir Tractor Plant that got the engines production for unloading KhTSZ in order to increase the re- lease of self-propelled chassis. Thus, the engine D-21 reached power nearly $20 \mathrm{HP}$ with the positive tolerance in different versions and D-21 reached $25 \mathrm{HP}$ at $1800 \mathrm{rpm}$.

A deep modernization of DVSSh-16 was conducted and the chassis T-16 were produced from 1961 to 1967. The operating speeds were increased on $10 \%$. Instead of one gear, there were two transmissions for transportation cargo in the cargo dump platform in a variety of road conditions. In this case, thanks to the gearboxes rational and compact design and front axle, chassis GVW was lowered to $1250 \mathrm{~kg}$ versus $1600 \mathrm{~kg}$ of DSSh-14m.

This chassis used remote-cylinder hydraulic system of the unified type, consisting of a gear hydraulic pump NSh-10 with the capacity of 10 litres per minute and a pressure of $100 \mathrm{~kg} / \mathrm{cm}^{2}$, two spool distributor $\mathrm{P}-75-2 \mathrm{~V}$ and two remote power cylinders capable for working together and separately.

Exactly this self-propelled chassis T-16 became the basis for all future upgrades and enhancements.

Since 1967, the plant produced T-16M chassis with rigid cabin having an inner protective shell that protected the tractor operator from serious injury even in a side rollover.

The most advanced chassis T-16MG (SSh-25) was created based on T-16M and released in the 70's. Various significant improvements were carried out in almost all the major components and systems of the chassis during several years. Such improvements resulted in sharply increasing of the service period (from 5-6 to 8-10 years) and rising of the machine reliability at whole (up to 0,992) at 3000-hours pilot tests in a machinetesting stations V/O "Soyuzselhoztehnika". This operational reliability coefficient was determined by the prevailing standard as quotient of the dividing working time in operating hours by the amount of the time and operating time in hours for failures finding and eliminating and then multiplied on a conversion factor of $\mathrm{x}=1.25$ for transfer in operation hours.

The chassis had a single suspension seat with seat belts, windshield wipers (electric front and manual rear), a rear three-point mounted system like the classic layout tractor had. This allowed chassis to work with the machines and tools of tractor T-25 as well as applied a layered hitch (front, face and back) to run three operations in a single pass. The rear light and two front were mounted and so on.

Kharkiv Tractor Assembling Plant (and now Kharkiv Plant of Self-Propelled Chassis - KhZTSSh) produced up to 25600 self-propelled chassis per year during 70-80 years of the last century, compared to the several thousand in the early $60 \mathrm{~s}$.

The need of the self-propelled chassis of 0.6 tons usually ranged 100-125 thousand vehicles a year so each vehicle released was on strict accounting and distributed only centrally.

To complete the overall assessment of the performance of KhZTSSh, it should be emphasized that its employees invented and protected by copyright certificates fundamentally new ways of front linkage machines and tools under the chassis frame that essentially decided at least two problems: 
- the sharp decline in working time for one operation of the hitch that was close to the classic layout tractors with the rear hinge;

- the ability to hang machines and tools hinged to the rear of the classic layout tractor.

As an example, we can name the construction of a self-propelled chassis with swiveling front axle designed by A. I. Vasernis, S. E. Libtsis, A. I. Podrigalo [6], as well as the construction of a self-propelled chassis with a lifting frame designed by a group of authors headed by V. A. Shapiro [7].

Unfortunately, the collapse of the Soviet Union almost did not allow realizing the revolutionary solutions that should made self-propelled chassis quite competitive in comparison with the classic layout tractors.

The self-propelled chassis manufactured by KhTSZ (KhZTSSh) were adopted as a power base in $20 \mathrm{de}-$ partments of the national economy. More than 200 mounted machines and implements were produced for these chassis.

A special tea modification allowed mechanized tea leaves harvesting was created based on a selfpropelled chassis T-16. The set of these machines included a special cultivator, fumigator, duster, sprayer, lateral turning mower, tea harvesting machine "Sakartvelo" and many others $[8,9]$.

To show the wide use of self-propelled chassis KhZTSSh we should remember the Latvian machines complex for patching asphalt pavement containing hole-borers, mowers, pesticides sprayers, mowers side, asphalt heaters and others. A marking machine produced by Kaliningrad Road Machines Plant was widely used in many cities for road marking. The ground lubricating units on the chassis base worked in the mines at depths up to 400 meters. The mobile drilling units on the chassis base worked at airfields for drilling wells in the concrete under the landing lights. The rubber mixing and punching machines based on selfpropelled chassis worked in the aluminum industry.

KhZTSSh produced up to 25600 self-propelled chassis per year in 70-80 years of the last century versus a few thousand at the beginning of the 60's. Over 0.5 million such agricultural tractors were produced during the Soviet years. The need in 0,6 ton self-propelled chassis usually fluctuated in the range of 100-125 thousand vehicles a year so each landing gear was in the strictest accounting and only centrally distributed.

It should be emphasized that KhZTSSh workers invented and protected by copyright certificates new ways of front gear control machines and instruments under the chassis frame that solved at least two problems:

- dramatically reduce the complexity of the selfpropelled sample to the values of the rear accessories;

- ability to hang the machines and tools on the back batch of classic layout tractor.

\section{Conclusion}

We should mention that Kharkiv Tractor Assembling Plant - KhTSZ (and now - Kharkiv Plant of Self- propelled Chassis - KhZTSSh) takes a special place in the development of Soviet and Ukrainian tractorbuilding, because it has been probably the only one plant producing various models of unconventional layout tractors for agriculture and for many other sectors of the economy. The plant began producing of self-propelled chassis in 1956. Studying the mechanics opinions and considering their priority wishes the plant replaced manufactured chassis model with a more progressive almost every 2 years. Over the 1949-1991 plant produced many models of tractors but its main products were self-propelled chassis in 1956. Issue of self-propelled chassis has not lost relevance today.

\section{References}

1. Adolf V. A. A short guide to a self-propelled chassis T-16 and DVSSh-16 [Text] / V. A. Adolf, A. I. Vasernis, S. E. Libtsis, I. N. Serebrjakov. - Moscow: "Space", 1964. -264 p.

2. Libtsis, S. E. Universal tilled self-propelled chassis. Theory and calculation [Text] / S. E. Libtsis. - Moscow: "Engineering", 1976. $-216 \mathrm{p}$.

3. Kurganov, A. I. Bases for design calculation of the chassis tractors and cars [Text] / A. I. Kurganov. - Moscow: State Publishing House of Agricultural Literature, 1953. -611 p.

4. 1949-1952 years on Kharkov Tractor Assembly plant (KhTSSH) [Text] / State Archives of Kharkiv region. Fund WF-5592, inventory № 1.

5. 1953-1970 on KhTSSh (later - KhZTSSh) [Text] / State Archives of Kharkiv region. Fund WF-5592, inventory № 2.

6. USSR Author's Certificate №206932.

7. USSR Author's Certificate №233319.

8. A list of cases of permanent storage on the Kharkiv Tractor Plant named after Ordzhonikidze 1929-1961 [Text] / State Archives of Kharkiv region. Fund WF-5652, inventory № 1.

9. A list of cases of permanent storage on the Kharkiv Tractor Plant named after Ordzhonikidze 1932-1970 [Text] / State Archives of Kharkiv region. Fund WF-5652, inventory № 4.

\section{References}

1. Adolf, V. A., Vasernis, A. I., Libtsis, S. E., Serebrjakov, I. N. (1964). A short guide to a self-propelled chassis T-16 and DVSSh-16. Moscow: "Space", 264.

2. Libtsis, S. E. (1976). Universal tilled self-propelled chassis. Theory and calculation. Moscow: "Engineering", 216.

3. Kurganov, A. I. (1953). Bases for design calculation of the chassis tractors and cars. Moscow: State Publishing House of Agricultural Literature, 611.

4. 1949-1952 years on Kharkov Tractor Assembly plant (KhTSSH). State Archives of Kharkiv region. Fund WF5592, inventory №1.

5. 1953-1970 on KhTSSh (later - KhZTSSh). State Archives of Kharkiv region. Fund WF-5592, inventory № 2.

6. USSR Author's Certificate №206932.

7. USSR Author's Certificate №233319.

8. A list of cases of permanent storage on the Kharkiv Tractor Plant named after Ordzhonikidze 1929-1961. State Archives of Kharkiv region. Fund WF-5652, inventory № 1.

9. A list of cases of permanent storage on the Kharkiv Tractor Plant named after Ordzhonikidze 1932-1970. State Archives of Kharkiv region. Fund WF-5652, inventory № 4.

Рекомендовано до публікації д-р істор. наук Савчук В. С. Дата надходження рукопису 27.03.2015

Kryvokon Alexander, PhD, Associate professor, Department of Automobile and Tractor Building, National Technical University “Kharkiv Polytechnic Institute”, Frunze str., 21, Kharkiv, Ukraine, 61002

E-mail: kryvokon@mail.ru 